Katarzyna Dębska

ORCID: https://orcid.org/0000-0003-4802-7686 Institute of Sociology, University of Warsaw ${ }^{1}$

Katarzyna Suwada

ORCID: https://orcid.org/0000-0001-8785-855X Institute of Sociology, Nicolaus Copernicus University in Toruń2

\title{
Social relations of people experiencing unemployment. Between support and stigmatisation
}

\begin{abstract}
The aim of the article is to analyse social relations of people experiencing unemployment in today's Polish society on the basis of the data collected as a part of the "Memoirs of the Unemployed" project. In this paper, we investigate three types of relations: with family, with friends and acquaintances, and with labour market institutions. Our analysis shows that the experience of unemployment has a specific impact on social relations, both within the family and with other people. They are characterised by great ambivalence, which results from the fact that although they are a source of support, they are often based on
\end{abstract}

1 Correspondence: Katarzyna Dębska, Institute of Sociology, University of Warsaw, ul. Karowa 18, 00-324 Warsaw, Poland; author's email address: k.debska@is.uw.edu.pl

2 Correspondence: Katarzyna Suwada, Institute of Sociology, University of Nicolaus Copernicus, ul. Fosa Staromiejska 1a, 87-100 Toruń, Poland; author's email address: k.suwada@umk.pl 
a lack of understanding of the situation of people experiencing unemployment, and even involve stigmatisation. The relations with representatives of institutions are perceived by the research participants as instrumental and stigmatising.

Key words: Unemployment, social relations, stigmatisation, diaries of the unemployed

\section{Introduction}

At the beginning of the 21st century, Polish society is characterised by the lowest unemployment rates after 1989. In the fourth quarter of 2018 the unemployment rate according to Labour Force Survey) was 3.8, so it was lower by almost 13 percentage points than in the fourth quarter of $2008^{3}$. Therefore, it seems that unemployment is no longer the most important challenge for social policy. However, although the data are optimistic, from the perspective of individuals who have lost their gainful employment and/or cannot find another one, unemployment is still a problem, a difficult experience that has a negative impact on their lives. The aim of our article is to look at the issue of unemployment in the context of the social relations an individual has. Here we analyse three types of relations: (1) family relationships, (2) relationships with friends and acquaintances, (3) relationships resulting from the institutional environment of a person experiencing unemployment. The context of our deliberations is the problem of social exclusion and stigmatisation, which result from the social pressure to have a paid job and be independent. In societies based on the neoliberal logic, everyone is expected to be economically active, and the people who do not meet this requirement (if they do not have a legitimate excuse such as illness, advanced age and, in case of women, also childcare) are assessed as lazy, failing, preying on the social welfare system and, consequently, are being slowly excluded from social relations (Lahusen \& Giugni, 2016; Tomescu-Dubrow et al., 2019). Gainful employment gives individuals an opportunity to build social relations, and thus the lack of such work cuts individuals off from social contacts (Michon, 2017). On the other hand, as it was shown by the research on young people, strong family ties weaken the negative consequences of unemployment (Binder, 2016; Michon, 2017), and strong ties established during employment help in finding a new job (Pawlak \& Kotnarowski, 2016). Therefore, we can observe a double relationship between unemployment and social relations: on the one hand, unemployment negatively affects the possibility of establishing social relations and can foster social exclusion, on the other hand, strong social relations can be a source of support for people experiencing unemployment and can help them find a job.

${ }_{3}$ Data from the Statistics Poland (GUS) (bdl.stat.gov.pl/). 


\section{Unemployment, the dictate of work and social relations}

From a social policy perspective, unemployment is treated as a social problem, and the unemployed are exposed to a whole range of other problems resulting from the lack of paid work, in particular those related to the lack of financial resources and quality of life, mental and health problems, as well as other manifestations of social inequality (Błędowski \& Karwacki, 2020). The value of the individual in the neoliberal paradigm is a resultant of how they find themselves and function in the labour market. Individuals who, for various reasons, are not successful in this area, are exposed to the lack of acceptance, social stigma and sometimes even social exclusion (Szahaj, 2017). All this has an impact on how people experiencing unemployment ${ }^{4}$ build social relations within the family, with friends and acquaintances, as well as with representatives of labour market and social welfare institutions in their local environment. As early as in the 1970s, Mark Granovetter (1973) emphasised the role of social ties in finding a job - his research has shown that the so-called weak ties, i.e. contacts with acquaintances, which are less intense than family relationships, are most helpful when it comes to finding employment. The replication of Granovetter's research in Polish society between 2013-2015 confirmed that even today in Polish society such contacts are more often used to search for employment than the formal channels. These are mostly contacts established at work, and less often contacts with people from the local community or family (Pawlak \& Kotnarowski, 2016). At the same time, the studies by Pawlak and Kotnarowski indicate that people experiencing unemployment have relatively fewer opportunities to use weak links to find employment and more often use family contacts, formal ways of looking for a job or report directly to the employers.

An important context related to the expectations arising from the dictate of work is the socio-cultural gender dimension. Research shows that women and men experience unemployment differently, as well as build social relations, both family and with friends and acquaintances, in a different way. Gender beliefs determine how women and men engage in different types of everyday practices, as well as what others expect from them in relation to different social roles they play (Ridgeway \& Correll, 2004). In this context, the way men and women experience unemployment is entirely different - in case of a man, professional work and the role of the main breadwinner of the family is often the main axis around which he builds his identity of "a real man", and thus the experience of unemployment directly affects his position in his family and society (Stier, 2014). In case of women, the dictate of work is weakened by cultural expectations related to family and domestic responsibilities. Women's unemployment, especially in situations of maternity or the need to care for other dependants in the family, is often considered natural and desirable. For women, work is to be an additional activity that should not prevent them

4 We perceive unemployment as a situation, an experience that individuals need to cope with, however, we try to avoid connoting unemployment with individuals' identities and personal traits therefore we do not use the term "the unemployed people" when referring to the participants of the study. 
from fulfilling other family responsibilities. Thus, women experience unemployment in a less drastic way than men, although at the same time they face greater barriers when they want to enter or return to the labour market (Stier, 2014; Tomescu-Dubrow et al., 2019).

By examining the experiences of unemployment, we take the perspective that the experiences of individuals are analysed in the context of their biographies. Both diaries and biographical interviews are used by biographers to analyse the history of life in the context of broader social processes (Dulczewski, 1975, p. 75). By analysing the biographical interviews and the diaries of the subjects, we show different variants of the impact of unemployment on the relationships in which individuals remain, while taking into account such dimensions of differentiation as gender or family status.

\section{Methodology}

The analysis is based on the material collected as part of the "Memoirs of the Unemployed. The experience of unemployment and trajectories of exclusion from the perspective of social policy and sociology" 5 . The authors of the diaries interpreted the term "unemployment" in various ways: some of them referred to the legal definition of "an unemployed person" 6 , others defined their situation of unemployment despite not meeting the legal requirements of being assigned to the status (which is followed by the right to health insurance and - in specific cases - to unemployment benefit). The project was divided into two stages. In the first stage, as part of a nationwide competition for the diary of a person experiencing unemployment organised by the Warsaw School of Economics, 373 diaries were collected from people who experience or have experienced unemployment for at least one month between 2016 and 2017. Ten authors of the diaries were selected for the second stage, which was individual case studies. The selection of cases was deliberate; the research participants were selected to represent the three unemployment trajectories distinguished at the earlier stage of the study: decline, duration, and success. Additionally, gender, age and the place of residence were taken into consideration while the cases were being selected. The case studies included biographical interviews with people experiencing unemployment, in-depth interviews with members of their families and/or other significant persons, as well as representatives of local labour administration and social welfare institutions. The analysis presented here is based on a qualitative analysis of diaries and the data collected during the field research. The material has been analysed in terms of relations and contacts with other people, which the research participants have. We searched for the dominant patterns of establishing, maintaining and disintegrating social relations.

5 The project was financed by the National Science Centre, funding scheme OPUS 11, grant no UMO-2016/21/B/HS5/03198.

6 According to Employment Promotion and Labour Market Institutions Act of 20 April 2004 (art. 2 point 2), an unemployed person is one that is not employed, does not perform paid work, capable of and ready to undertake full time employment. 
Family relationships

Family relationships of people experiencing unemployment are characterised with great ambivalence. On the one hand, our research confirms Florian Znaniecki's thesis (1992) that the unemployed are more focused on family relationships than on relations with friends (especially those they got to know at work). On the other hand, the situation of unemployment has a (negative) impact not only on the person who has lost their job, but also on other members of the family.

The first characteristic feature of family relationships is the dependence of a person experiencing unemployment on other family members. It manifests itself in two dimensions: economy-related (financial dependence) and care-related (obligation to take care of children and other dependents). The issue of financial dependence dominates in men's narratives. They refer to the model of masculinity based on the role of the main breadwinner - a real man should be a father who is able to support his family financially (Suwada, 2017). The situation of unemployment makes the person who was responsible for supporting the family become a person who has to be supported. There is a strong violation of the family model based on traditional gender roles, which for unemployed husbands and fathers is associated with a sense of shame and discomfort, resulting from the loss of the decision-making position in the family:

After all, I am a man, a husband, a father, a grandfather. I should carry the support of my family on my shoulders, bring money to it. And what do I bring? (...). I'm ashamed that I can't provide for my family. (MD10, 61 years old, unemployed for over 2 years $)^{7}$

I didn't notice to consume less because my wife earns some of the two lowest Polish average salaries, but when we were shopping for clothes, I stood aside a little so as not to be asked by my wife - to buy or not buy. I stopped being a decision-maker at home, a full member. The clothes bought for me were kind of gifts and I felt a bit silly. (MD41, 42 years old, unemployed for 6-12 months)

In such a situation, men experiencing unemployment often withdraw from family life and perceive themselves as redundant within the family. This can (indirectly) lead to the break-up of the family and even to the breaking of relations with their children (see also: Karwacki \& Suwada, 2020).

At the same time, the family can also be a support for a person without employment. On the one hand, therefore, we have a sense of dependence, which takes away agency and gives a sense of redundancy, but on the other hand, the orientation of men towards the family is clear. Relationships with the loved ones allow for everyday functioning, even if there are no real chances for improvement.

7 The quotations were translated from Polish. The abbreviations after the quotations describe the research participant and the source of the quotation: $\mathrm{M}-$ man, $\mathrm{W}-$ woman, $\mathrm{D}-$ diary, I - interview, J - researcher's journal. 
We wouldn't talk if my wife wasn't with me. When I got to the hospital, when [the company] collapsed, she was with me when [the boss] kicked my ass, and every time anything bad happened to me. And now, unfortunately, she shares it all with me. All what I messed up. (MI1, 50 years old, unemployed for 12-24 months)

The support is perhaps most evident in the case of young men who are unable to become independent without paid work. They often live at home with their parents, and sometimes even with their grandparents, and intergenerational relationships are the most important elements of their daily lives. Such a situation also triggers a sense of ambivalence. On the one hand, living with parents is often perceived by other family members as a burden, and a young person experiencing unemployment feels pressure to move out of the house and finally become independent.

In their eyes, I'm now a loser who, after a failed attempt to live in the capital, ended up on his parents' couch. I don't think so. It's just a transition period. (MD53, 33 years old, unemployed for 6-12 months)

On the other hand, young people living with older parents also help them in their daily life.

Here I have a situation that, just for the moment, until my mother retires, I have to be with them, I have to, because I have such a responsibility and such a need, that... we are creating this kind of, maybe you can say, basic unit, we are the three of us, but everyone, everyone is trying to do... something for someone else, we try to support ourselves and help each other. (MI2, 32 years old, unemployed for more than 2 years)

This support in everyday life can be counted as a second form of dependence within family relationships. Much more often it concerns women and is primarily related to childcare. The experiences of the participants of the study indicate a huge problem related to discrimination on the labour market due to motherhood. Their unemployment is often associated with pregnancy: women are dismissed after the parental leave period (contrary to current regulations), and mothers of small children have a problem with finding a job because they are asked about their children and procreation plans during interviews. Similar experiences do not appear in men's narratives; even when they take care of a child at home, it is never a topic for discussion during their recruitment processes:

Well, I've started to go to the next interviews, and here, nothing, if you'll pardon my expression. Everyone: 'Well, because you have a child here'. And it started, yeah, all the time about this child. And there was such a situation, there was a nice conversation in one company, (...) but the woman, I remember, I felt terrible, I even cried, when I left, she immediately let me know: 'Oh, well, and you have a child? And how old is the child?' (...) And later, the more I looked for, yeah, I started to bounce back from that wall, because everywhere I looked, the question about the child was asked, as if, I don't know, I don't know, I had ball and chain at my leg and wasn't suitable for anything. (WI1, 30 years old, unemployed for over 2 years) 
In a sense, women's unemployment is often functional for the family, since it helps to plug the gap in care resulting from the state's inefficiency (lack of an adequate number of places for children in nurseries and kindergartens, lack of institutional support system for the elderly and people with disabilities). Women's narratives show a strong social conviction that a mother should be with her children up to the age of three (the so-called "myth of threeness", see: Saxonberg, 2014).

Do you really want to leave your children with a random woman? Up to the age of three, a child should be with their mother. Well, look at them. How could you leave them with a stranger? They need you. And you've been breast-feeding Anna for too short." (I fed her for a year and 7 months). (WD15, 36 years old, unemployed for 6-12 months)

Since I've had my babies, I've been wondering about a 1-year maternal leave. I thought about the time with the children. I reckon that until they are three, children need a mother, right? (WI3, 37 years old, unemployed for 6-12 months)

In addition, other household duties that would otherwise have to be performed by other family members, are transferred to women experiencing unemployment:

Recently, the unemployed [the labour office] gave me an internship, and my mum actually said to my fiancé that it would be good if I didn't get the internship. Because they'd have more responsibilities. (WI2, 28 years old, unemployed for over 2 years)

Although it seems functional from a family perspective, such a situation also generates conflicts. Those arise primarily from the sense of underestimation of housework and care work and the excessive burden of household responsibilities. The stress associated with the feeling of financial insecurity is also significant - one working person feels pressure and responsibility for supporting the whole family.

Another characteristic feature of family relations is the problem of stigmatisation and marginalisation of people experiencing unemployment by the family. This applies both to close relatives (who provide support on a daily basis) and other family members who are unable to put themselves in the situation of a person experiencing unemployment.

After a while, my mother began to preach. She wasn't happy — that's a little bit of a statement: 'Oh God! The next millenial is here. Working in a company doesn't satisfy you, so now you'll be wandering around the world instead of starting a family, buying an apartment and finally settling down. (...) What will I tell my friends? Everybody admired you so much, admired that you were doing well in Warsaw, that you handled your life. And now? (MD53, 33 years old, unemployed for 6-12 months)

[The opinion of adult daughters] Why the hell don't you make money? At the same time, our mother can bring home several thousand zlotys a month. (MD31, 58 years old, unemployed for over 2 years) 
The stigmatisation on the part of the family members mainly concerns men. When it comes to women, especially those with small children, there is no problem of family's negative assessment connected with the lack of paid work.

An extreme situation is the trajectory of decline, in which a person experiences longterm unemployment overlapping with other problems, e.g. homelessness, chronic physical or mental illness, debts and bailiff sentences. The common feature of such situations is the limited family support or the lack of it:

A man who becomes unemployed and has a family has protection. Either he has someone who works and shares the income, or he has someone who doesn't work and takes benefits, or he has a basement with 200 jars of preserves. I have nothing. For me, cutting off the cash is like tearing off a gasoline cable, a gasoline cable in a car on a field road. (MI4, 56 years old, unemployed for 12-24 months)

In this context, although the family relationships of individuals experiencing unemployment are marked by a certain ambivalence, they are an important source of support, not only emotional but also financial, which allows them to continue functioning with basic sense of security and protects an individual from complete social marginalisation.

\section{Friends and acquaintances}

The notion of friends, acquaintances appears in some stories in the context of inability to find a job through traditional recruitment:

[about cousins] each one of them is working, each one of them has a job arranged through inside contacts, each one of them got married, each one of them inherited a house or an apartment. (MI2, 32 years old, unemployed for over 2 years)

Some people without paid work feel frustrated with the feeling that only inside contacts and connections allow them to get employment. In this sense, friendships are presented as a blameworthy item that contribute to the deepening of inequalities in the labour market.

Maybe, finally, it would be good to take up this, once again, I will use the word 'diehard', this nepotism, this old-boyism, and, finally, set all this, and to make sure that the regulations are... made in such a way that... there is no possibility of this type of employment without, without a limit of different types of acquaintances, distant relatives, and this type of thing. (MI2, 32 years old, unemployed for over 2 years)

Men more often than women have complained that certain job opportunities are closed to them due to employers' greater inclination to hire friends or recommended people. In some cases, those interviewees who criticised the bonds based on friendship, had, usually a few, experiences of "getting things done through inside contacts" (e.g. a job, an internship). The role of having friends (social capital) is confirmed by Granovetter's thesis (1973) on the power of weak ties. The conviction connected with finding employment 
through contacts is confirmed by statistical data - as Pawlak and Kotnarowski demonstrate, this is the most common way of finding employment (49.1\% out of those surveyed found employment thanks to personal contacts) (Pawlak \& Kotnarowski, 2016, p. 199). These weak links, as shown by Wegener (1991), for example, are more important in case of people with greater resources (e.g. cultural capital) and applying for jobs on higher positions than in case of people with low initial capital, aiming to move from the dominated social structure positions to higher ones. The importance of such links is visible, inter alia, in the area of creative work, like in the case of a participant who started to develop her artistic activity while experiencing unemployment:

And somehow I have creative friends all my life, someone makes music, someone writes, someone paints. And I've always attracted such people, so the things I do now are so much easier for me to do, because I've always had these people next to me. (WI1, 30 years old, unemployed for over 2 years)

The men who experience unemployment more often than women in the same situation do not have friends or have no closer contacts with them:

And I also have, I have just a few friends, but I don't have a whole lot of friends, but I have all the same people all the time that I talk to and see... (...) I appreciate this too, these, these things, especially since I'm such a person, some people can't make lasting friendships, after two years they just look away and pretend we don't know each other. (MI3, 27 years old, unemployed for 6-12 months)

Sociological research on friendship indicates greater emotionality and intimacy in relations between women (Johnson, 1996, p. 79). Such a claim has been criticised as reducing the model of friendship relations to a single model (Inman, 1996), that equates the understanding of femininity to relationality, emotionality, and caring. In some cases, the ability to build support ties on the basis of discussing the problems gives a chance to get out of a difficult situation. This may be exemplified by the story of a forty-year-old participant who has experienced various forms of violence from her husband for many years and, wanting to part with her husband, had to find a job to provide for herself and her children. While talking about her healing process, she points out the important role played by the women she met along the way:

Then I found a wonderful woman, a psychiatrist. (...) I've been seeing her once in a while for many years, and she got me out of it, she prescribed me medication, she approached me with such great understanding, and then it turned out that (...) she was going through a similar situation (...) it gives me strength, because, I mean, my psychiatrist, my current boss now and my friend, they are all women who went through exactly the same thing. (WI4, 40 years old, unemployed for 12-24 months)

Among young men experiencing unemployment who are forced to live with their parents and unable to develop professionally, there is a criticism of the superficiality of the popular way of creating and maintaining bonds through social media: 
Now we've just got errr zombie kids, as they often say about being stuck to the screen all the time, errr without such real close friendships and acquaintances, (...) that somebody has a lot of likes on Facebook, or errrr, or a lot of friends in social media, errr often, well, it's just often not true. Errrr why isn't it real? Well, we just have errr just an example, if errr some bad situation happens, a lot of people have bad experiences that most of their friends turn aside. If you lose money, most of your friends turn aside. (MI2, 32 years old, unemployed for over 2 years)

Such views do not have to be accompanied by intensive friendly practices developed outside the Internet. Such argumentation can also be interpreted as a way of rationalising the weaknesses of one's own friendship bonds.

The question of having friends and acquaintances and maintaining these bonds does not depend only on individual preferences or tempers, but is influenced by structural mechanisms. The possibility of having friends also depends on one's amount of free time (O'Connor, 1992). It is not a rule that people who do not work have a lot of free time: some are burdened with the duty of taking care of the dependent family members (children, elderly parents, etc.), housework (cooking, cleaning, etc.) or the activities aiming at finding work. A partner of one of the survey participants even questioned the term "unemployed" in relation to her partner because he takes up a lot of activities on a daily basis: he takes care of their little child, takes his partner to work and his son to kindergarten, does shopping, cooks, cleans and improves his qualifications by taking part in various courses. Moreover, as it was mentioned above, people without stable employment often experience psychological difficulties, which discourages them from maintaining social contacts with people from outside the family. Friends can also exert pressure on an individual that the individual feels as negative. The pressure is connected with the fact that he or she does not follow a lifestyle that is taken for granted and therefore desirable in that environment:

In the eyes of my friends, I was the one who was unemployed. And everyone has always teased me. (...) Hahaha! And what, your husband provides for you? Haha, and what, are you looking for work? For how long? Do you stay at home? (WI3, 37 years old, unemployed for 6-12 months)

Friends and acquaintances can provide valuable resources for individuals experiencing unemployment. They can support them mentally, help them to find a job, motivate them. In the analysed material, there are no examples of financial support provided by friends and acquaintances, which reflects the predominant familial pattern of transferring money between individuals in Poland (there is a greater tendency to give or lend money to the members of one's family than to the people from outside, even if they are friends) (Giza-Poleszczuk, 1992; Kochanowicz \& Marody, 2003). There are, however, cases in which friends and acquaintances make an individual sure that they are in an unfavourable environment, that they do not meet some expectations. At this point, one can put forward a thesis about a kind of friendship endogamy - it is easier to make friends with people similar to us, also in terms of social and financial status, which translates into practices, values and problems faced by individuals and families. 
In the analysed material, women had more intense social relations than men. The possibilities of making and maintaining intensive friendships with friends and acquaintances depend not only on individual preferences, but are rooted in the social experience of individuals: gender-based patterns of creating close relations, amount of free time or health. People experiencing unemployment often lack do not have sufficient resources to maintain intensive relations with friends and acquaintances.

\section{Institutional environment of an individual in the situation of unemployment}

Some research participants see the seeming nature of the work of labour offices, which primarily serve as providers of health insurance:

The contact with the people who are there looks exactly like this: I know that I'm there to get the documents proving my unemployment, which gives me health care and they know that I'm there to get that. Everything else is bullshit. (MI5, 60 years old, unemployed for over two years)

As one of the research participants described it, to a labour office clerk the signing of a declaration of readiness to work as a pro forma action (JM5), and the facade nature of it is understood by both sides of this interaction. The same research participant decided to resign from being registered in the labour office, and thus also from the right to health insurance (at the same time not being able to obtain the title to insurance from other sources), thus wanting to realise his freedom (JM5).

The unemployed experiences of contacts with people working in labour offices are almost always associated with negative feelings: frustration, anger, helplessness, and even shame or humiliation. Some people have decided to confront employees of labour offices, others have tried to maintain correct relations with them without showing their dissatisfaction. Negative stories about the experiences of the contacts with labour offices employees are sometimes contradicted by the memory of one person who has given a jobseeker special support:

We started talking and I'm telling her about this theatre and that's when the idea started, to make shows for children started, and she started motivating me somehow: 'Oh, that's so cool, that's for sure, do it.' And she was the only person who, YES, actually [helped me]. (WI1, 30 years old, unemployed for over 2 years)

Clients of labour offices feel as supplicants who have to meet their obligations, and not as people who are entitled to support:

On the one hand, you could say that I'm used to it, but I don't like to go to the labour office, (...) but on the other hand, errr every time it's the day before I'm supposed to go to the office, my mood is already changing for the worse. No, there's no willingness to help at all, it's just about signing, checking in and just going back (...) to your errr unemployment. (MI2, 32 years old, unemployed for over 2 years). 
The above quotation proves the officials' lack of interest in the reality of the informant's life. Visits to the labour office undermine the self-esteem of interviewees and their hope for change. Interestingly, in interviews with employees of labour offices (career advisers and job mediators), which were also carried out within the framework of this study, it was repeatedly declared that one of the important objectives of the work of the labour office is to strengthen self-confidence and self-esteem of clients, and motivate them to be active. Perhaps the strong element of conditionality inherent in the system of job placement makes it impossible to establish a satisfactory relationship for both the persons registered in labour offices and their employees.

Persons with higher education often receive the message that they have high but inadequate qualifications for the labour market, are over-educated, and therefore somehow bear responsibility for their difficult situation, which manifests itself in a tendency to individualise responsibility for the fact of lack of employment:

I don't have to go to miss Zosia, Tosia or Halinka to explain to them (...) why I graduated from sociology, for example. (...) 'Ha, ha, with such an education, we do not have a job for you'. 'WITH SUCH AN EDUCATION'. (WI1, 30 years old, unemployed for over 2 years)

The few ways in which the research participants show their dissatisfaction with the assistance offered in labour offices bring with them a sense of fear that revealing their critical attitude towards officials may make their situation worse - now or in the future. Moreover, it happens that the employees of labour offices try to match a person experiencing unemployment with their job offers:

I don't know whether to laugh or cry, my career counsellor told me that the results of my tests have shown errr my analytical mind, empathy, sensitivity to others and such things. (...) Errr, but after all this, errrr, after all this, errr the lady, with disarming honesty, said that one day a gentleman came to her, a little older than me, errrr and she 'made a decent human being out of him'. She made a decent human being out of him, she sent him to forklifting courses. (MI2, 32 years old, unemployed for over 2 years)

The research participant quoted above experienced a sense of disillusionment and being cheated because he thought that higher education would guarantee him a good job. The counsellor's need to make him "a decent human being" is an additional evidence of the lack of social recognition for his efforts to get an education.

People with low qualifications feel that nobody wants to give them a chance to test their abilities in practice or gain experience. It happens that competence tests and evaluations of the chances of finding employment by people who experience unemployment do not motivate them to look for a job, but actually undermine them:

I also did such competence tests, but when I read how they came out, I didn't go to these further meetings because I cracked up, to be honest. (WI4, 40 years old, unemployed for 12-24 months) 
In such a case, it is the individual that builds up the belief that they have a deficit that does not allow them to change their professional situation.

The necessity to appear in the office within the prescribed time limit and to report on one's progress in the job search process is in many cases connected with the feeling of being restricted in one's own freedom and being able to decide on one's actions. One of the research participants pointed out the lack of flexibility and understanding of women from the labour office, who do not accept not showing up at the office even when the child is ill:

I called them and said I would like to postpone err because of the [sick] child. (in a higher voice) 'THEN YOU HAVE TO COME EARLIER, TOMORROW, AND SIGN'. So I came and this lady, of course, gave me the whole lecture there, that I wouldn't be entitled to insurance, because 'If you are not able to work because you have a child, please sign out' and so on. (WI1, 30 years old, unemployed for over 2 years)

Another source of frustration in contacts with the labour office was the unsatisfactory offer of support from the office. It happens that people in a situation of unemployment feel that they have to look for the opportunities that the job centre has to offer them:

All these activities seem to be my initiative. I found out what I could do, and I searched the Internet. (WI4, 56 years old, unemployed for 12-24 months)

I haven't had a single offer of any kind during the whole period of being registered in the labour office. All that, any help, any internship errr that came from the labour office, errrr, was the result of several visits. (MI2, 32 years old, unemployed for more than 2 years)

The contact with the labour office can be perceived as stigmatising, both in the context of the social environment's perception of one's situation, and the need to contact officials on the side of the "client" or "supplicant" (the latter term seems to reflect better the experiences of a great part of the research participants).

\section{Summary}

Our analysis of the unemployment experience in the Polish society in the second decade of the 21st century indicates that unemployment is a factor that has a specific impact on social relations. Family relationships of people experiencing unemployment are marked by ambivalence - on the one hand, family is an important source of financial and psychological support in a situation of unemployment, on the other hand, these relationships are often characterised by dependence that has a negative impact on the people experiencing unemployment. Gender is an important dimension in this context. In case of men in family relationships, they more often experience stigmatisation and lack of understanding from their close family members. In turn, female unemployment is more likely to be functional for the family, as it involves assigning of many caring and household 
duties to the woman in a situation of unemployment. In a sense, female unemployment allows to "plug" the gap in care resulting from insufficient institutional support within different care institutions. Different patterns of relationship building between women and men can also be observed in their relations with friends and acquaintances. In case of women, these relationships more often provide support and allow themselves to be helped in situations of unemployment. Men, on the other hand, are more likely to point to negative pressure from friends who cannot understand the situation of unemployment according to the applicable norms resulting from the neoliberal dictate of work. However, the people experiencing unemployment of both genders often do not have appropriate resources to maintain such relationships. The most negative experiences are described by the research participants in the context of relations with representatives of local labour market institutions and aid institutions. These relations are described as instrumental, devoid of empathy and understanding, and often stigmatising. Research participants experience frustration, anger, as well as disappointment with the way they are treated by the workers of institutions.

The above analysis leads to the conclusion that the experience of unemployment has a negative impact on social relations, which in the long run translates into growing social isolation of people experiencing unemployment. Weak ties (Granovetter, 1973) constitute the main way of finding a new job in society, and the situation of unemployment significantly weakens them, making it more difficult to find a job through these ties.

\section{References}

Binder, P. (2016). Coping with Long-Term Unemployment in Poland: Faces of Joblessness in a Regional Centre. In C. Lahusen \& M. Giugni (eds.), Experiencing Long-Term Unemployment in Europe: Youth on the Edge. (171-207). Palgrave Macmillan.

Błędowski, P., \& Karwacki, K. (2020). Bezrobocie jako współczesna kwestia społeczna aspekty socjologiczne i ekonomiczne, Studia Socjologiczne, 236(1), 135-164. https:// doi.org/ 10.24425/sts.2020.132454

Dulczewski, Z. (1975). Florian Znaniecki jako twórca metody autobiograficznej w socjologii. In A. Kwilecki (ed.), Florian Znaniecki i jego rola $w$ socjologii, Wydawnictwo Naukowe UAM.

Giza-Poleszczuk, A. (1992). Familism and System Transformation. The Polish Sociological Bulletin, 3/4, 315-327.

Granovetter, M. (1973). The Strength of Weak Ties. American Journal of Sociology, 78(6), 1360-1380.

Inman, C. (1996). Friendships Among Men: Closeness in the Doing. In J. T. Wood (ed.), Gendered Relationships. Mayfield Publishing Company.

Johnson, F. L. (1996). Friendship Among Women: Closeness in Dialogue. In J. T. Wood (ed.), Gendered Relationships. Mayfield Publishing Company. 
Karwacki, A., \& Suwada, K. (2020). Doświadczenie bezrobocia a relacje rodzinne we współczesnej Polsce — perspektywa płci. Studia Socjologiczne, 236(1), 165-194. https:// doi.org/10.24425/sts2020.132455

Kochanowicz, J., \& Marody, M. (2003). Towards Understanding Polish Economic Culture. Polish Sociological Review, 4, 1231-1413.

Lahusen, C., \& Giugni, M. (2016). Experiencing Long-Term Unemployment in Europe: An Introduction. In C. Lahusen \& M. Giugni (eds.), Experiencing Long-Term Unemployment in Europe - Youth on the Edge. (1-16), Palgrave Macmillan.

Michoń, P. (2017). Wpływ bezrobocia na subiektywny dobrostan osób młodych w Polsce. Polityka Społeczna, 8, 41-46.

O'Connor, P. (1992). Friendships between women: A critical review. Guilford Press.

Pawlak, M., \& Kotnarowski, M. (2016). Siła słabych powiązań na rynku pracy w Polsce. Studia Socjologiczne, 221(2), 187-215.

Ridgeway, C. L., \& Correll, S. J. (2004). Unpacking the Gender System A Theoretical Perspective on Gender Beliefs and Social Relations. Gender \& Society, 18(4), 510-531. https://doi.org/10.1177/0891243204265269

Saxonberg, S. (2014). Gendering family policies in post-Communist Europe: A historical-institutional analysis. Palgrave Macmillan.

Stier, R. (2014). Unemployment and Fatherhood: Gender, Culture and National Context. Gender, Work \& Organization, 21(5), 395-410. https://doi.org/10.1111/gwao.12044.

Suwada, K. (2017). Men, Fathering and the Gender Trap. Sweden and Poland Compared. Palgrave Macmillan.

Szahaj, A. (2017). Neoliberalizm turbokapitalizm kryzys. Książka i Prasa.

Tomescu-Dubrow, I., Dubrow J.K., Kiersztyn A., Andrejuk K., Kołczyńska M., \& Słomczyński K.M. (2019). The subjective experience of joblessness in Poland. Springer.

Wegener, B. (1991). Job mobility and social ties: social resources, prior job, and status attainment. American Sociological Review, 56(1), 60-71. https://doi.org/10.2307/2095673

Znaniecki, F. (1992). Socjologia bezrobotnych. Kultura i Społeczeństwo, 1, 3-13. 